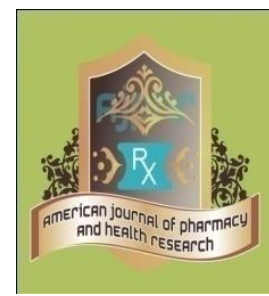

\title{
Formulation and Characterization of Telavancin Proniosomal Gel for Topical Delivery
}

\author{
Kishori*1, $^{*}$ V. Felix Joe ${ }^{1}$ \\ 1.Department of Pharmaceutics, Shree Devi College of Pharmacy, Airport Road, Kenjar, \\ Mangaluru- 574142, Karnataka, India.
}

\begin{abstract}
Vesicular systems provide large opportunities for the transdermal delivery of therapeutics. The present study was designed to investigate the potential of a novel class of vesicular system 'proniosome' as a carrier for transdermal delivery of telavancin. Proniosome formulations were prepared by co-acervation phase separation method. The developed system was characterized for drug release, zeta potential, particle size analysis and kinetics. Span 60 was the most appropriate surfactant, and yielded vesicle size and percentage encapsulation efficiency respectively. The in vitro telavancin proniosomes formulations exhibited a sustained release for $7 \mathrm{hrs}$. Zeta potential was found to be $-32.7 \mathrm{mv}$ which indicates the stability of the formulation. The proniosomes F6 formulation shows entrapment efficiency of $92.7 \%$. From the diffusion study it was found that formulation F6 shows the highest drug permeation. F1 followed zero order release kinetic profile; F2 was first order release kinetic profile and for F3 to F7 followed Peppa's model drug release kinetic profile. Formulations stored at refrigeration condition $\left(8 \pm 2{ }^{\circ} \mathrm{C}\right)$ showed a higher drug entrapment when compared to the formulations stored at accelerated condition $\left(30 \pm 2{ }^{0} \mathrm{C}\right)$ at $(65 \pm 5 \% \mathrm{RH})$ after a period of 4 weeks.
\end{abstract}

Keywords: Proniosomes, Telavancin, In vitro drug release and release kinetics

*Corresponding Author Email: kishorikula195@gmail.com

Received 10 July 2020, Accepted 22 July 2020

Please cite this article as: Kishori et al., Formulation and Characterization Of Telavancin Proniosomal Gel For Topical Delivery . American Journal of Pharmacy \& Health Research 2020. 


\section{INTRODUCTION}

In the past few decades, considerable attention has been focused on the development of new drug delivery system named controlled drug delivery system. The objective for the development of controlled release forms is to prolong the duration of action, increased safety of margin of high potency drugs due to better control of plasma level, reduce fluctuation in plasma concentration, and reduce the serious side effect. ${ }^{1}$

Vesicular carriers are colloidal particle in which a concentric bilayer made up of amphiphilic molecule surrounds an aqueous compartment. These amphiphilic molecules via, phospholipids, surfactants (non-ionic, ionic or combination) are either present separately or in combination along with cholesterol as fluidity buffer. ${ }^{2}$ proniosomes are dry formation of surfactant coated carrier, which can be measured out as needed and rehydrated by brief agitation in hot water. ${ }^{3}$

The niosomes can be prepared from the pro-niosomes by adding different types of aqueous phase with the drug to the proniosomes with agitation and formation of niosomes from proniosomes. The surfactant molecule direct themselves such that the hydrophilic end of the non-ionic surfactants orient outward, while the hydrophobic end are in the opposite direction to form the bilayer. Like liposomes proniosomes are also made of bilayer. In proniosomes this bilayer are made up of nonionic surface active agent. ${ }^{4}$

Antibiotic medications are widely used in the treatment and prevention of such infections. They may either kill or inhibit the growth of bacteria. Antibiotics aren't effective against viral infections, such as the common cold, flu most cough and sore throats. ${ }^{5}$

Telavancin is a lipoglycopeptide antimicrobial agent under development for use in the treatment of multidrug resistant gram-positive infections. It inhibits cell-wall biosynthesis by binding to latestage cell-wall precursors. The activity of telavancin is due to the novel combined action on the cell wall synthesis and disruption of bacterial cell membrane barrier function. The mechanism of inhibition of cell wall synthesis is similar to that of vancomycin. The glycopeptides core binds to the terminal acyl-dalanyl- $d$-alanine chains of the cell wall with high affinity by means of hydrogen bonds and hydrophobic packing interaction. ${ }^{6}$ In the present work an attempt made to develop and evaluate the telavancin as proniosomal gel in order to eliminate the GIT side effect, to incorporate insoluble drug, and to enhance the percutaneous absorption.

\section{MATERIALS AND METHOD}

\section{Materials}


Telavancin was procured from Sigma Aldrich, Mumbai, Cholestrol, Span 60, Carbopol 934P was procured from Oxford lab fine chem LLP, Mumbai, Soya lecithin was procured from Yarrow chemicals, Mumbai. All the chemicals and reagents were used of analytical grade.

\section{Methods}

\section{Formulation of telavancin proniosomal gel}

Proniosomes of telavancin were prepared by already reported co-acervation phase separation method with slight modification. ${ }^{7}$ Briefly, Weighed amount of surfactant; lecithin, cholesterol, drug and Ethanol were taken in a wide mouthed glass vial. Mixture is warmed over water bath at $60-70{ }^{\circ} \mathrm{C}$ until the mixture dissolves completely. To the resultant mixture phosphate buffer $\mathrm{pH} 7.4$ was added and heated in a water bath to obtain a clear solution which was then cooled at room temperature and mixed with equal volume of $1 \%$ carbopol gel to obtain clear proniosomal gel. The composition of telavancin proniosomes were given in Table 1.

\section{Table 1: Composition of telavancin Proniosomes}

\begin{tabular}{lllll}
\hline $\begin{array}{l}\text { Formulation } \\
\text { Code }\end{array}$ & $\begin{array}{l}\text { Telavancin } \\
(\mathbf{m g})\end{array}$ & $\begin{array}{l}\text { Span } \\
(\mathbf{m g})\end{array}$ & $\begin{array}{l}\text { Cholesterol } \\
(\mathbf{m g})\end{array}$ & $\begin{array}{l}\text { Lecithin } \\
(\mathbf{m g})\end{array}$ \\
\hline F1 & 100 & 1350 & 321 & 900 \\
F2 & 100 & 1800 & 200 & 900 \\
F3 & 100 & 1350 & 179 & 900 \\
F4 & 100 & 900 & 300 & 900 \\
F5 & 100 & 900 & 200 & 900 \\
F6 & 100 & 714 & 250 & 900 \\
F7 & 100 & 1986 & 250 & 900 \\
\hline
\end{tabular}

$10 \mathrm{mg}$ equivalent weight of proniosomes was incorporated in carbopol gel to obtain $1 \% \mathrm{w} / \mathrm{w}$ telavancin proniosomal gel.

\section{Characterization of proniosomal gel}

\section{Measurement of pH}

The $\mathrm{pH}$ of proniosomal formulation was determined by using digital $\mathrm{pH}$ meter.1gm of gel was dissolved in $100 \mathrm{ml}$ of distilled water and was placed for $2 \mathrm{hr}$. The measurement of $\mathrm{pH}$ of each formulation was done in triplicate and average values were calculated. ${ }^{\mathbf{8}}$

\section{Viscosity determination}

Brookfield viscometer was used for viscosity determination. The formulation $(10 \mathrm{~g})$ was taken and it was allowed to calibrate for $5 \mathrm{~min}$ before measuring the dial reading using spindle No 64 at 20 $\mathrm{rpm}^{8}$

\section{Vesicle Size Analysis}

The average size and size distribution measurement was carried out by dynamic light scattering with zeta sizer (Malvern instruments Ltd).The freshly prepared hydrated niosomes were dispersed 
in distilled water and was to characterize vesicle size. Polydispersity index was also determined as a measure of homogeneity. ${ }^{9}$

\section{Zeta Potential}

Measurement of zeta potential of the liposomal formulation was done by using a Malvern nano zeta sizer instrument. The zeta potential measurements were done at $25{ }^{0} \mathrm{C}$. ${ }^{9}$

\section{Spreadability}

The spreadability of the gel formulation was determined by taking two glass slides $(14 \times 5 \mathrm{~cm})$ of equal length. On one glass slide, $1 \mathrm{gm}$ gel was applied. To the other slide, weights are added and the time taken for the second glass slide to slip off from the first glass slide was determined.

Spreadability coefficient was determined by the formula

$$
\text { Spreadability Coefficient }=\frac{M \times l}{t}
$$

Where, $\mathrm{SC}=$ Spreadability coefficient

$\mathrm{M}=$ mass in gram,

l= length

$\mathrm{t}=$ time in seconds. ${ }^{8}$

\section{Entrapment Efficiency ${ }^{10}$}

Percentage entrapment efficiency was studied by centrifuge method. 100mg of proniosomal formulation was weighed and dispersed in $10 \mathrm{ml}$ of PBS $\mathrm{pH}$ 7.4. The obtained proniosomes dispersion was centrifuged at $10000 \mathrm{rpm}$ for $30 \mathrm{~min}$. The clear fraction (supernatant) was used for the determination of the free drug. The drug concentration in the resulting solution was assayed by UV spectrophotometer at absorption maxima. The percentage of drug encapsulation (Entrapment Efficiency percentage EE \%) was calculated by the following equation:

$$
\text { Entrapment Efficiency } \%=\frac{\text { Total amount of drug }- \text { Unentrapped drug }}{\text { Total amount of drug }} \times 100
$$

\section{Drug Content}

The drug content was determined by dissolving $100 \mathrm{mg}$ of proniosomal gel in $100 \mathrm{ml}$ of PBS pH 7.4. From this $1 \mathrm{ml}$ solution is diluted up to $100 \mathrm{ml}$ of $\mathrm{PBS} \mathrm{pH} 7.4$. Then the absorbance is measured by UV spectrophotometer against blank at $\lambda \max$ and the drug content was calculated

$$
\text { Amount of Drug }=\frac{\text { Concentration fron the standard graph } \times D F}{1000}
$$

Where DF $=$ dilution factor. ${ }^{11}$

\section{In Vitro Drug Permeation Study}


The in vitro drug release studies were carried out by using Franz diffusion assembly. Ten mg equivalent proniosomal preparation was placed on dialysis membrane between donor and receptor compartment of diffusion cell assembly. The receptor compartment was filled with PBS pH 7.4, magnetically stirred at $200 \mathrm{rpm}$. The drug content was determined by collecting $2 \mathrm{ml}$ receptor fluid every hour. The volume withdrawn was replaced with equal quantity of fresh buffer. After suitable dilution, the sample was a analyzed spectrophotometrically at $\lambda \max .^{\mathbf{1 2}}$

\section{IN-VITRO DRUG RELEASE KINETICS}

The dissolution profile of all the batches was fitted to Zero order, First order and Higuchi to ascertain the kinetic modelling of the drug release. The results obtained from in vitro release studies were plotted in four kinetics models of data treatment as follows:

- Cumulative percentage drug release Vs. Time (zero order rate kinetics)

- Log cumulative percentage drug retained Vs. Time (first order rate kinetics)

- Cumulative percentage drug release Vs. $\sqrt{T}$ (Higuchi classical diffusion equation)

- Log of cumulative percentage drug release Vs. log Time (Peppas exponential equation). ${ }^{\mathbf{1 3}}$

\section{STABILITY STUDIES:}

The stability study of the proniosomal preparation was determined by drug content and entrapment efficiency. The selected batch was packed in tightly closed containers wrapped in aluminium foil and kept at $30 \pm 20{ }^{\circ} \mathrm{C}$ at $(65 \pm 5 \% \mathrm{RH})$ for 4 weeks in a stability chamber and also at $8 \pm 20{ }^{\circ} \mathrm{C}$ temperature in a refrigerator. ${ }^{\mathbf{1 4}}$

\section{RESULTS AND DISCUSSION}

\section{Morphological Evaluation}

\section{Characterization of Proniosomal gel}

\section{Physical Appearance}

Table No: 2 shows the colour and physical state for each formula, these properties are different from each other, which depends upon the composition of each formulation.

\section{Table 2: Physical Appearance of Proniosomal formulations}

\begin{tabular}{lll}
\hline $\begin{array}{l}\text { Formulation } \\
\text { Code }\end{array}$ & Color & Physical State \\
\hline F1 & Brown & Liquid \\
F2 & White & Semisolid \\
F3 & White & Semisolid \\
F4 & White & Semisolid \\
F5 & Light-brown & Gel \\
F6 & Light-brown & Gel \\
F7 & Light-brown & Gel \\
\hline
\end{tabular}


Drug excipient Compatibility Study by FTIR:

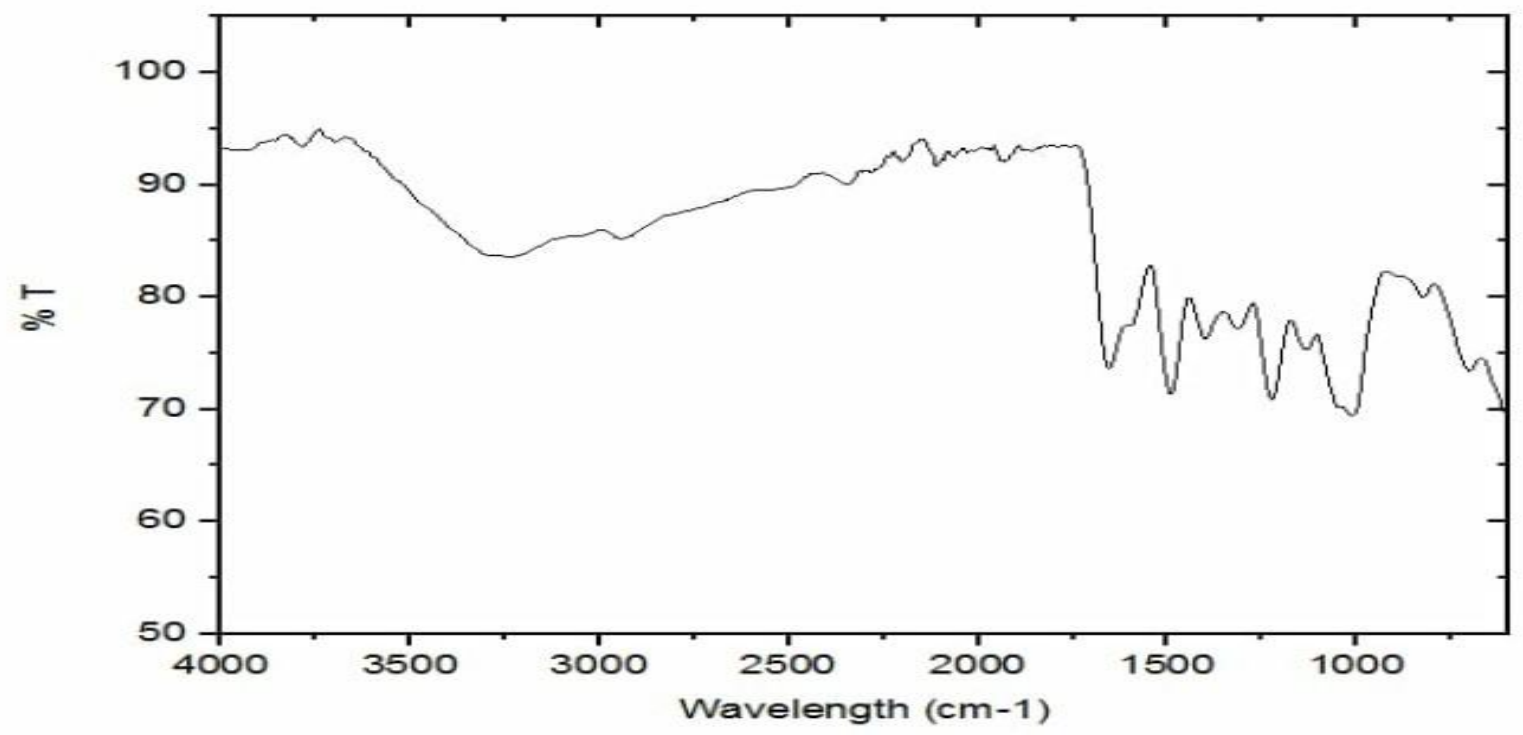

Figure 1(a): FTIR spectra of Telavancin

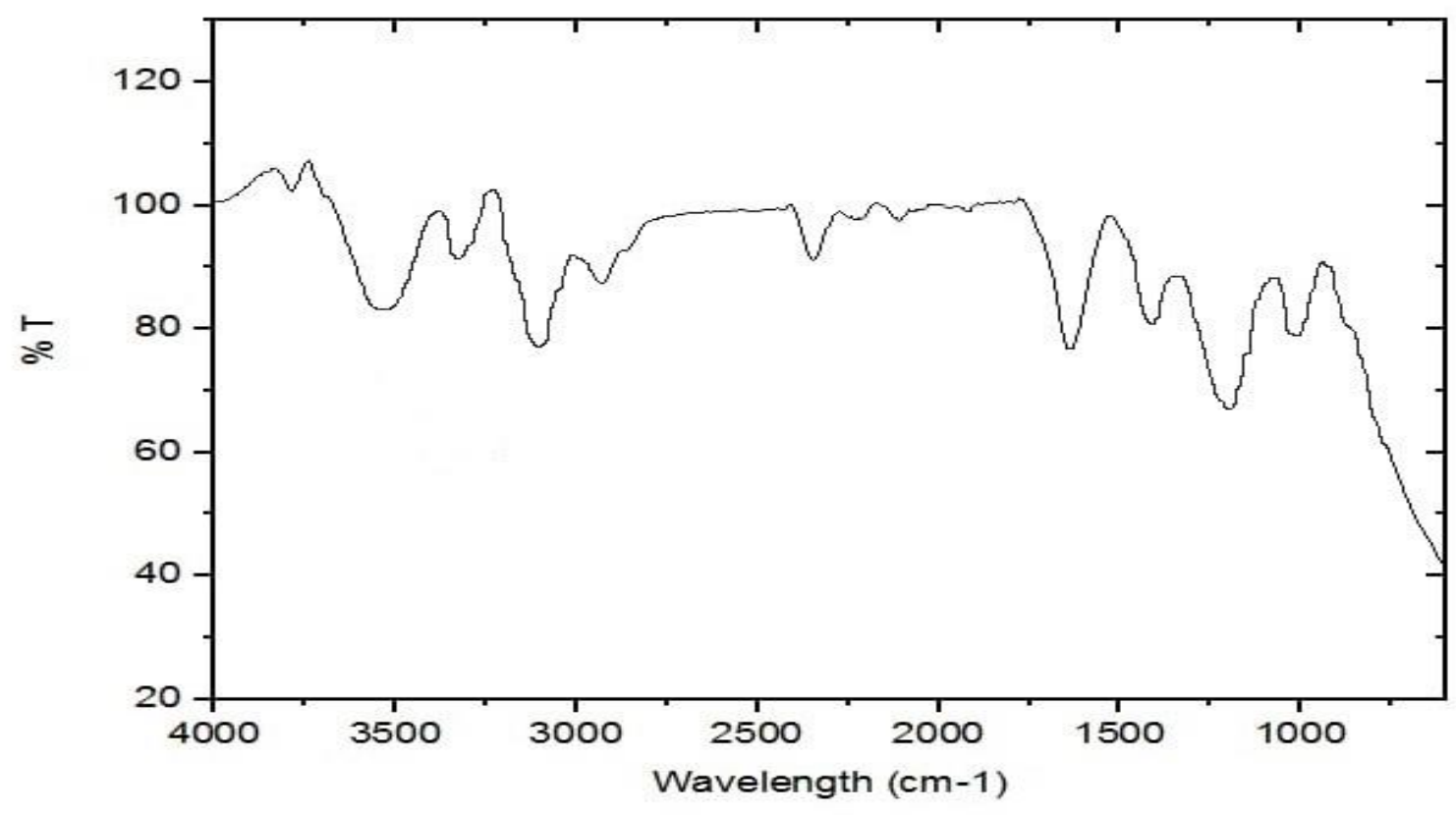

Figure 1(b): FTIR of Telavancin formulation 


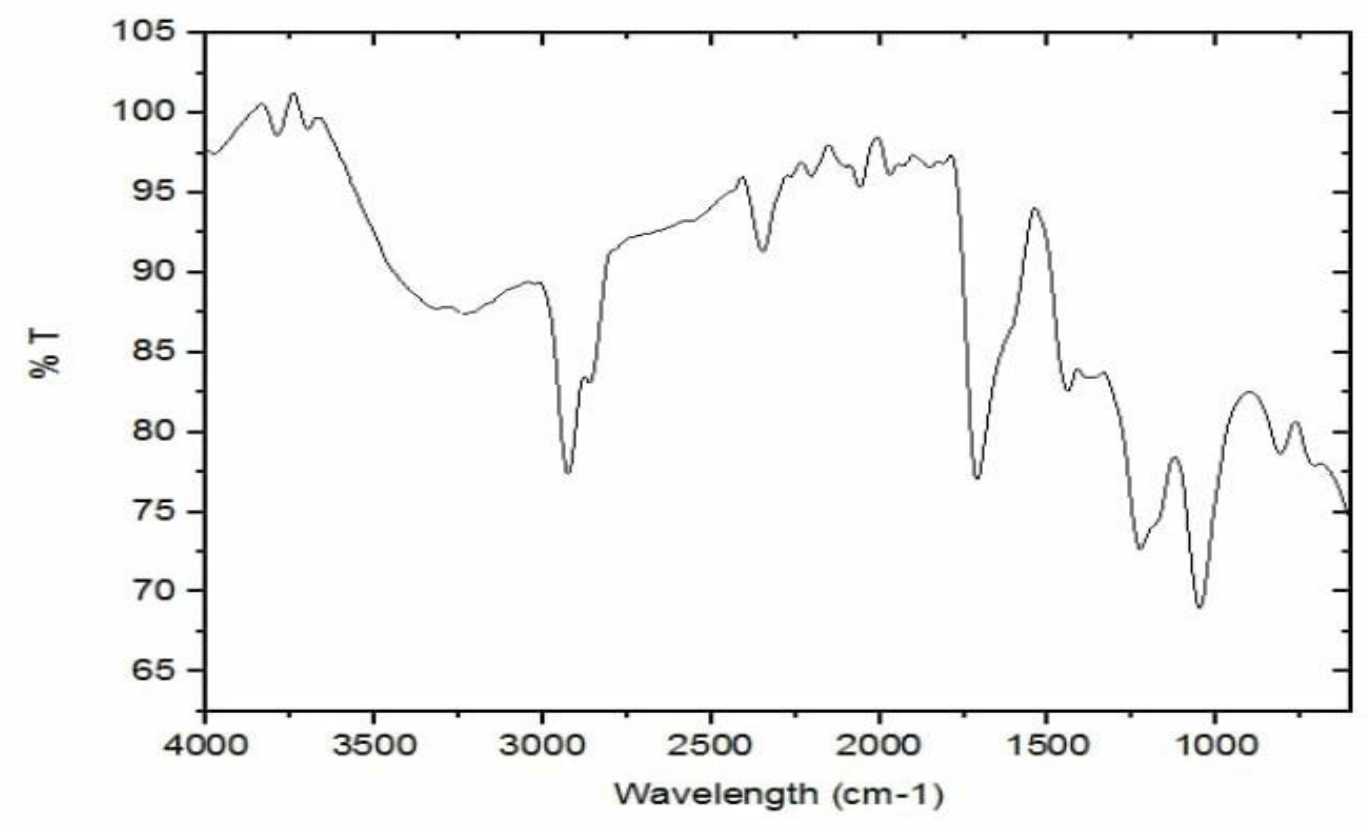

Figure 1(c): Telavancin + Cholestrol + Span $60+$ Soyalecithin + Carbopol gel

\section{Interpretation of FTIR spectra:}

FTIR spectrum of pure drug and physical mixture of drug and polymer were studied by using FTIR spectrophotometer. Drug, excipients interaction was studied before developing the formulation by using FTIR spectroscopy, which is one of the most important analyses to describe about the stability of formulation, presence of drug \& drug release IR spectrum of pure drug, drug+ excipients and formulation F6 to known the interactions between the drug and excipients.

- The principle peak of the pure drug was observed at $3381-3383 \mathrm{~cm}^{-1}(\mathrm{O}-\mathrm{H}), 1664-1708 \mathrm{~cm}^{-}$ ${ }^{1}(\mathrm{C}=\mathrm{O}), 1493 \mathrm{~cm}^{-1}, 1230 \mathrm{~cm}^{-1}(\mathrm{C}-\mathrm{O}-\mathrm{C}), 1062-1127 \mathrm{~cm}^{-1}(\mathrm{C}-\mathrm{N})$

- Peaks for the drug + excipients was observed at $2918 \mathrm{~cm}^{-1}(\mathrm{C}-\mathrm{H}), 1641 \mathrm{~cm}^{-1}(\mathrm{C}=\mathrm{O}), 1465$ $\mathrm{cm}^{-1}(\mathrm{C}=\mathrm{C})$.

- Peaks for the formulation F6 was observed at $2916 \mathrm{~cm}^{-1}(\mathrm{C}-\mathrm{H}), 1643 \mathrm{~cm}^{-1}(\mathrm{C}=\mathrm{O}), 1463 \mathrm{~cm}^{-}$ ${ }^{1}(\mathrm{C}=\mathrm{C})$.

\section{Vesicle size:}

Vesicle size analysis of the proniosomes determined using a Malvern zeta sizer. The Vesicle size of the prepared proniosomal gel for the optimized formulation F6 was found to be $4823 \mathrm{~d} . \mathrm{nm}$. The vesicle were discrete and separate with no aggregation or agglomeration. The results are shown in Figure 2 


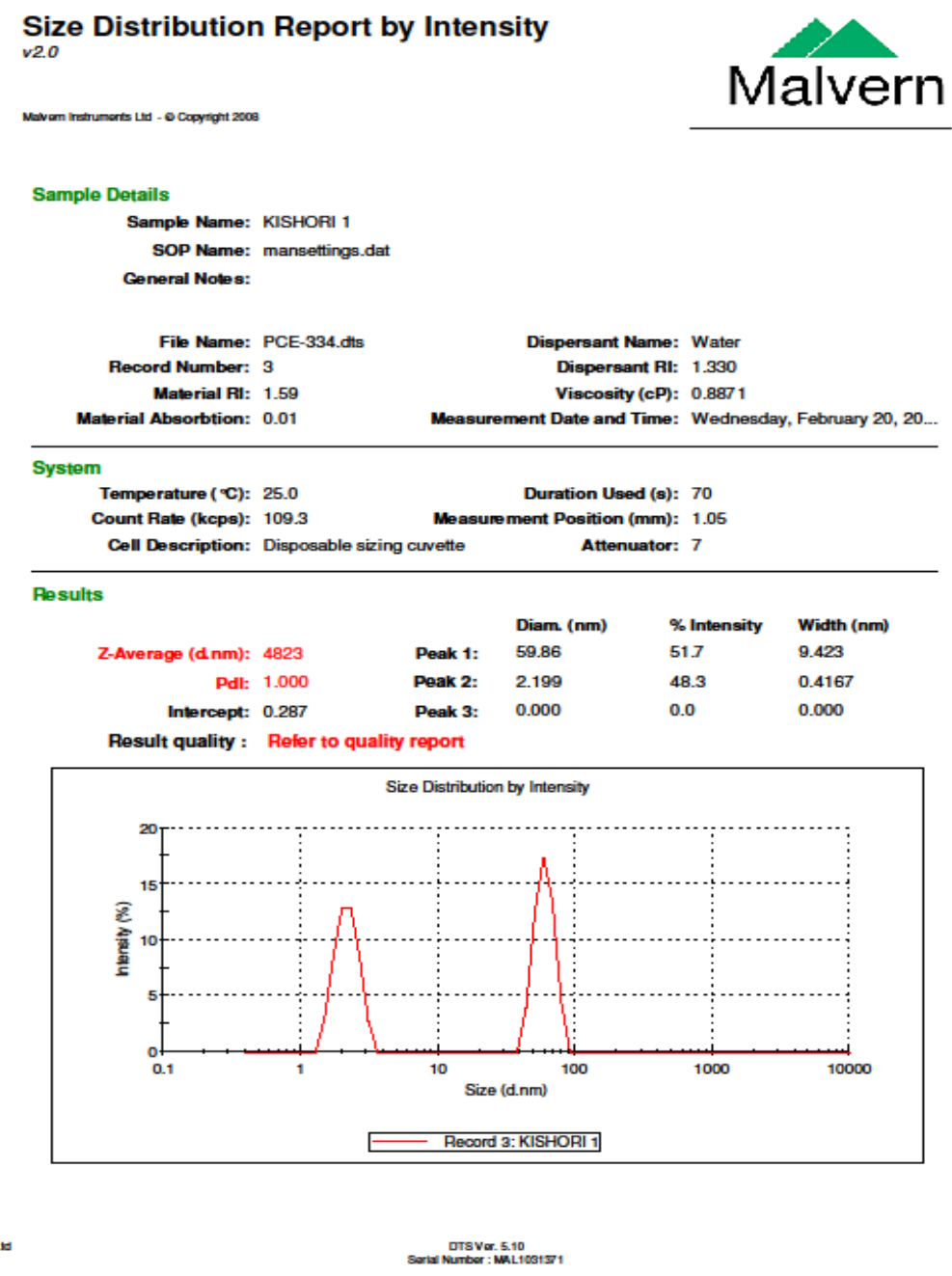

Figure 2: Vesicle size of F6 proniosomal formulation

\section{Zeta Potential:}

Zeta potential is another important index for the stability of the proniosomal formulation. The proniosomal formulation F6 that contains telavancin, Span 60, Cholesterol and lecithin as surfactants were subjected to appropriate dilution using ionized water where niosomes are derived and its dispersion was detected utilizing the zeta potential analyzer. The zeta potential value of the prepared telavancin optimized proniosomal preparation F6 was found to be $-32.7 \mathrm{mV}$. . The results are shown in Figure 3 


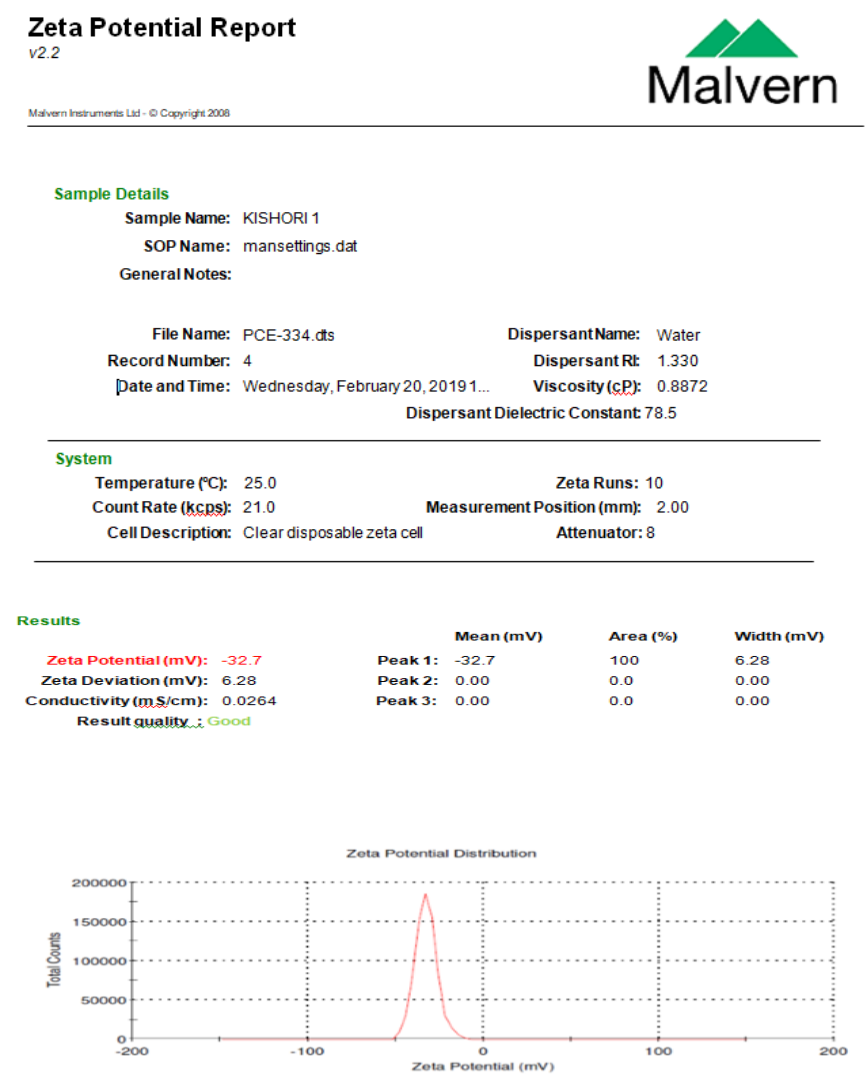

Figure 3: Zeta potential of F6 proniosomal formulation

Table 3: pH, Spreadability, Viscosity, Entrapment Efficiency and Drug Content of telavancin proniosomal gel

\begin{tabular}{|c|c|c|c|c|c|}
\hline $\begin{array}{l}\text { Formulation } \\
\text { code }\end{array}$ & $\begin{array}{l}\mathbf{p H} \\
(*)\end{array}$ & $\begin{array}{l}\text { Spreadability } \\
\text { (g } \\
\text { cm/sec } \pm \text { SD)* }\end{array}$ & $\begin{array}{l}\text { Viscosity } \\
\text { (cps) }\end{array}$ & $\begin{array}{l}\% \\
\text { Entrapment } \\
\text { Efficiency }\end{array}$ & $\begin{array}{l}\text { Drug } \\
\text { Content } \\
(\% \pm \text { SD })^{*}\end{array}$ \\
\hline F1 & $7.08 \pm 0.03$ & $23.6 \pm 0.2$ & 25380 & $63.5 \pm 0.35$ & $66.5 \pm 0.35$ \\
\hline $\mathrm{F} 2$ & $7.38 \pm 0.035$ & $22.27 \pm 0.2$ & 24890 & $57.5 \pm 0.35$ & $52.75 \pm 0.53$ \\
\hline F3 & $7.18 \pm 0.03$ & $20.79 \pm 0.1$ & 23650 & $73.5 \pm 0.3$ & $75.5 \pm 0.35$ \\
\hline F4 & $7.29 \pm 0.03$ & $22.67 \pm 0.3$ & 27680 & $62.5 \pm 0.35$ & $75.35 \pm 0.24$ \\
\hline F5 & $7.31 \pm 0.035$ & $20.91 \pm 0.6$ & 25720 & $81.6 \pm 0.3$ & $66.65 \pm 0.24$ \\
\hline F6 & $7.45 \pm 0.03$ & $28.9 \pm 0.05$ & 28640 & $92.7 \pm 0.3$ & $93.5 \pm 0.35$ \\
\hline F7 & $7.21 \pm 0.03$ & $23.6 \pm 0.2$ & 24320 & $66.2 \pm 0.35$ & $72.8 \pm 0.14$ \\
\hline
\end{tabular}

\section{pH and Spreadability:}

The $\mathrm{pH}$ of the formulation was determined in order to investigate the possibility of any side effects in vivo. The $\mathrm{pH}$ was found between 7 to 7.5 . This range is within the physiological skin surface $\mathrm{pH}$. The Spreadability of each formulation was determined and it is found within the range of 20$28 \mathrm{gcm} / \mathrm{sec}$. The results are given in Table 3 


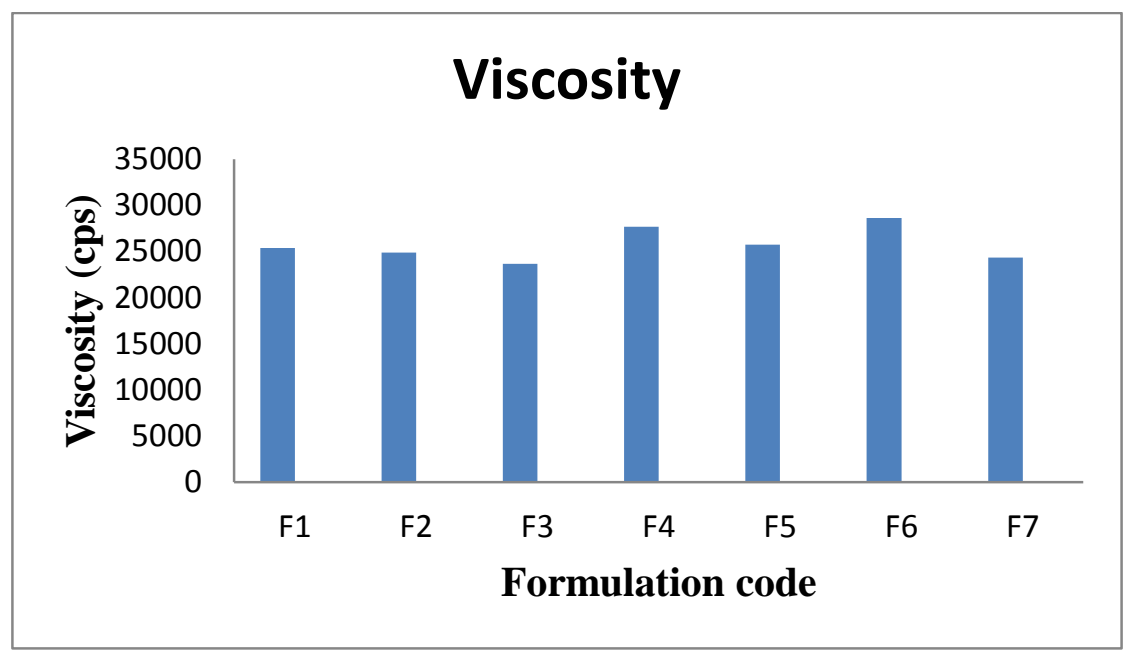

Figure 4: Composition of viscosity of F1- F7 proniosomal formulations

Viscosity measurement of all the proniosomal formulation revealed optimum consistency. The viscosity was found to be in the range of 23650-28640 cps. The results are given in Table No:3 and Composition of viscosity of F1- F7 proniosomal formulations are given in Table No:3

Entrapment Efficiency (EE)

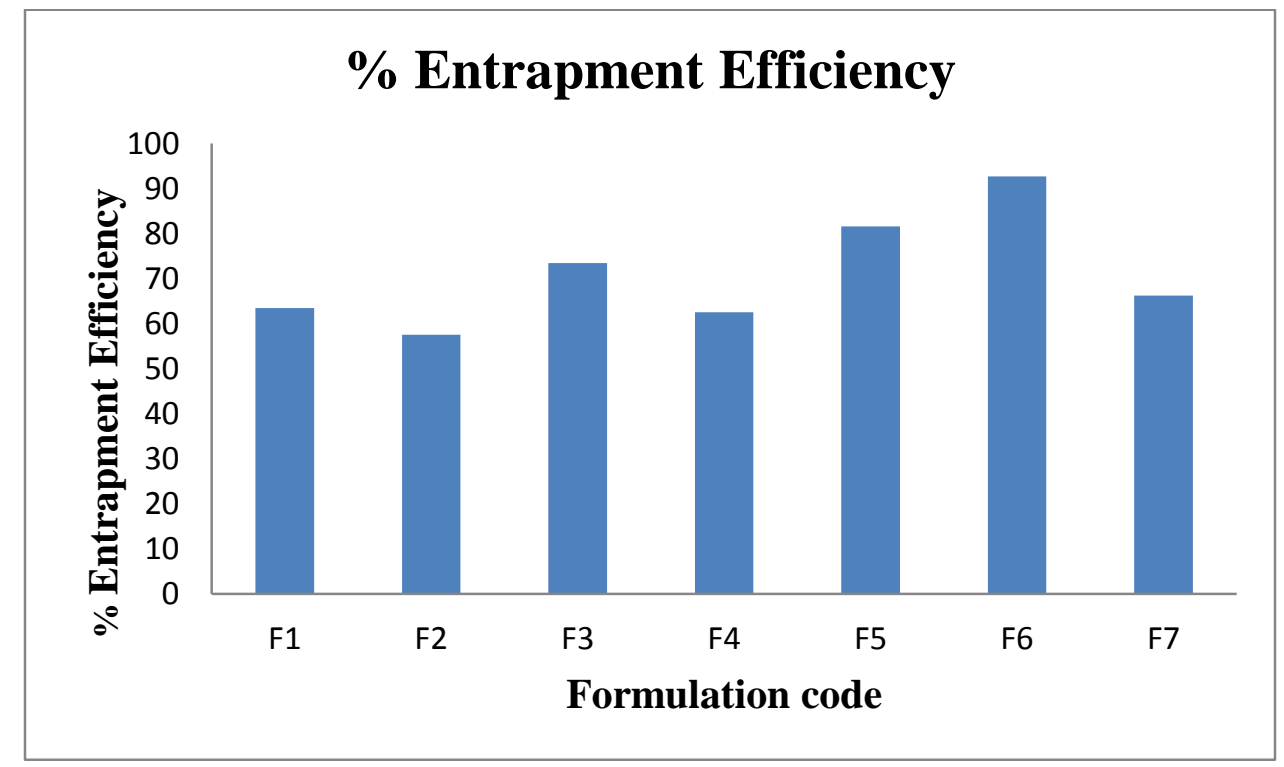

Figure 5: Composition of Entrapment efficiency of F1- F7 proniosomal formulations

Entrapment efficiency was studied for seven formulations to find the best formulation in terms of entrapment efficiency. The entrapment efficiency was found between 57.5 to $81.6 \%$. The EE was found to be higher with formulation No F6, which may have optimum cholesterol surfactant ratio to provide an entrapment for telavancin. Very low cholesterol content F2 was found to be cause low EE (57.5\%), which might be because of the leakage of the vesicles. It was also observed that very high cholesterol content (F1) has a lowering effect on drug entrapment to the vesicle (63.5\%) 
this could be due to the fact that cholesterol beyond the certain level starts disrupting the regular bilayered structure leading to loss of drug entrapment. The results were given in Table 3.

\section{Drug content:}

Uniformity in content of proniosomal gel was confirmed to assure uniformity in dosages. The drug content of the all formulation was found between 52.75 to $93.5 \%$. The results were given in Table 3.

\section{In vitro drug release:}

Table 4: In vitro release profile of telavancin proniosomal gel

\begin{tabular}{llllllll}
\hline $\begin{array}{l}\text { Time } \\
\text { (hr) }\end{array}$ & \% CDR & F2 & F3 & F4 & F5 & F6 & F7 \\
\hline 0 & 0 & 0 & 0 & 0 & 0 & 0 & 0 \\
1 & 8.32 & 13.83 & 11.20 & 14.43 & 9.10 & 14.02 & 13.54 \\
2 & 10.63 & 17.60 & 16.31 & 21.45 & 12.43 & 21.50 & 17.39 \\
3 & 14.20 & 26.14 & 20.50 & 27.49 & 15.72 & 32.47 & 26.05 \\
4 & 19.26 & 33.10 & 25.14 & 30.15 & 20.92 & 49.05 & 34.04 \\
5 & 34.59 & 48.21 & 36.07 & 45.23 & 42.70 & 57.29 & 43.18 \\
6 & 43.81 & 56.01 & 46.30 & 56.01 & 48.20 & 64.31 & 56.71 \\
7 & 56.34 & 65.16 & 59.21 & 70.42 & 55.03 & 72.01 & 63.11 \\
\hline
\end{tabular}

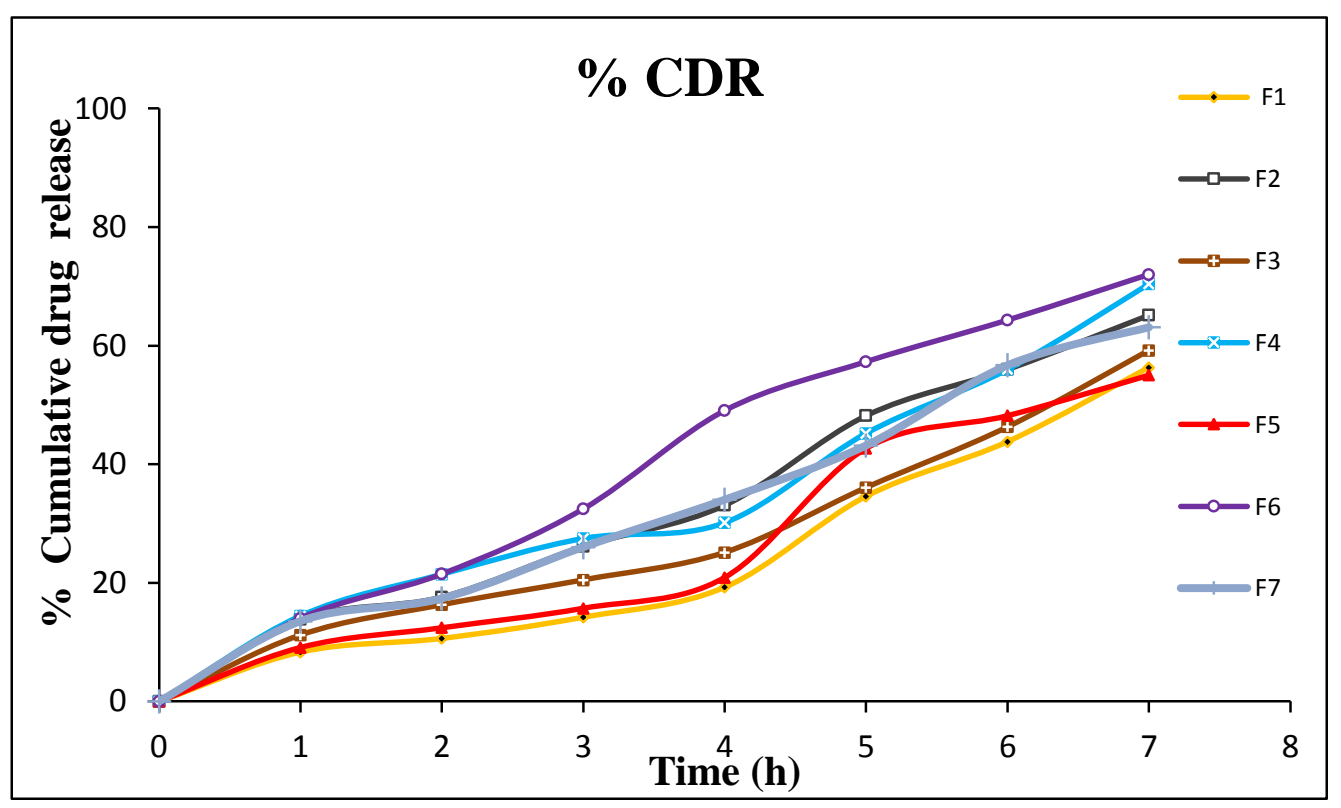

Figure 6: In vitro drug release profile for telavancin formulations

The diffusion method was used to investigate the in vitro telavancin release from proniosomes.

The percentage of the drug released after $7 \mathrm{hrs}$ from the proniosomal vesicles are shown in table 4. From the diffusion study it was found that formulation F2 shows the highest drug permeation $(72.01 \%)$. All the formulation shows the linear release at different time intervals. The results were given in Table 4. 
Kinetic study:

Table 5: kinetics data of proniosomal formulation

\begin{tabular}{llllll}
\hline $\begin{array}{l}\text { Formulation } \\
\text { code }\end{array}$ & $\begin{array}{l}\text { Zero } \\
\text { order }\end{array}$ & $\begin{array}{l}\text { First } \\
\text { order }\end{array}$ & $\begin{array}{l}\text { Peppa's } \\
\text { model } \\
\text { R2 } \\
\end{array}$ & & \multicolumn{2}{c}{$\begin{array}{l}\text { Higuchi } \\
\text { model }\end{array}$} \\
\hline F1 & 0.992 & 0.984 & 0.992 & 0.738 & 0.911 \\
F2 & 0.988 & 0.994 & 0.984 & 0.899 & 0.936 \\
F3 & 0.934 & 0.934 & 0.952 & 0.992 & 0.899 \\
F4 & 0.970 & 0.984 & 0.996 & 0.852 & 0.980 \\
F5 & 0.961 & 0.978 & 0.986 & 0.886 & 0.980 \\
F6 & 0.980 & 0.986 & 0.994 & 0.886 & 0.964 \\
F7 & 0.969 & 0.985 & 0.996 & 0.828 & 0.977 \\
\hline
\end{tabular}

Zero order:

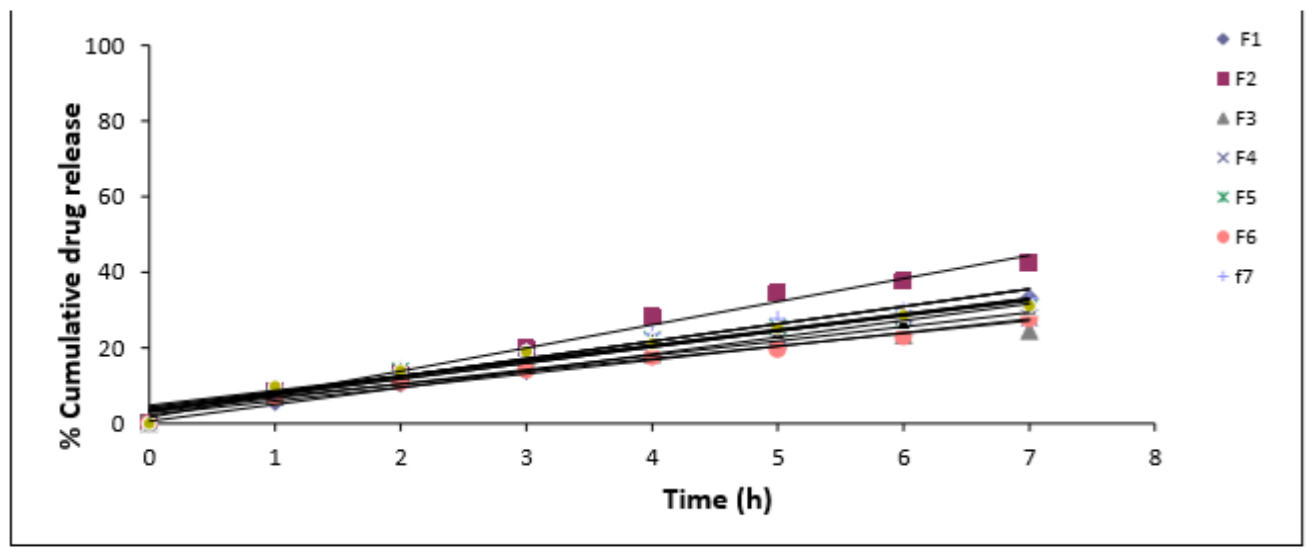

Figure 7(a) : plot of \% CDR v/s time (zero order)

First order

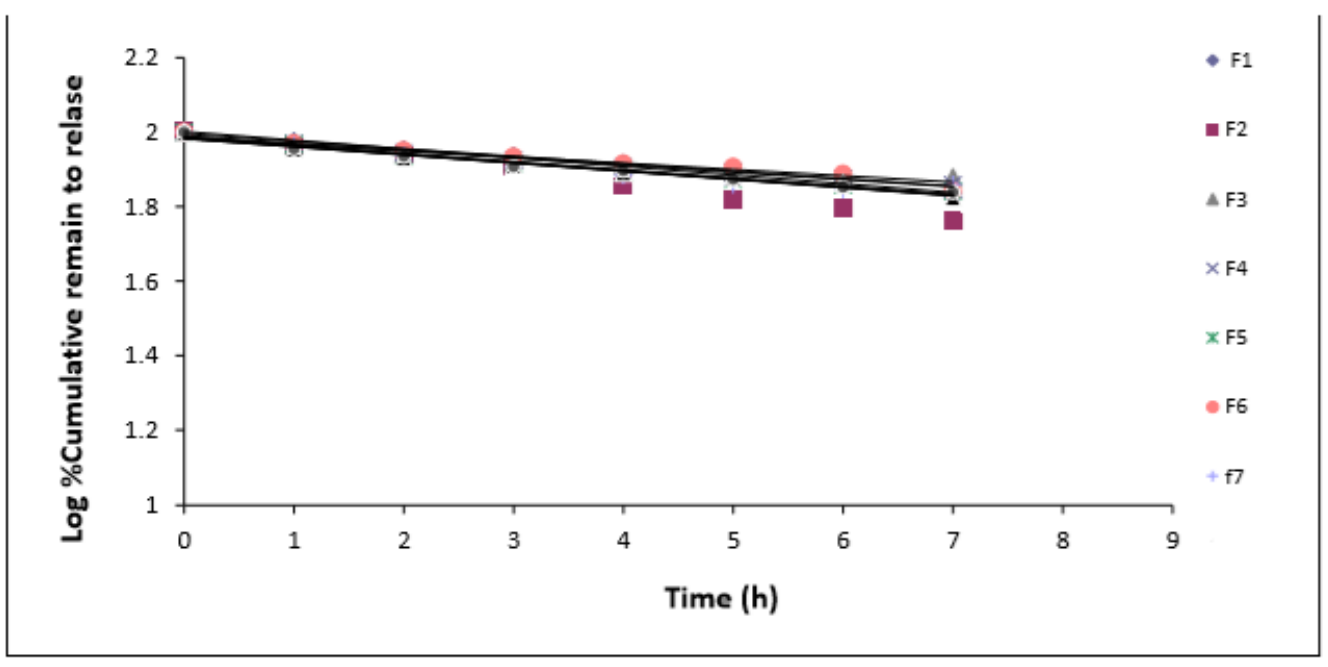

Figure 7(b): plot of $\log \%$ CDR v/s time (first order) 


\section{Peppa's model}

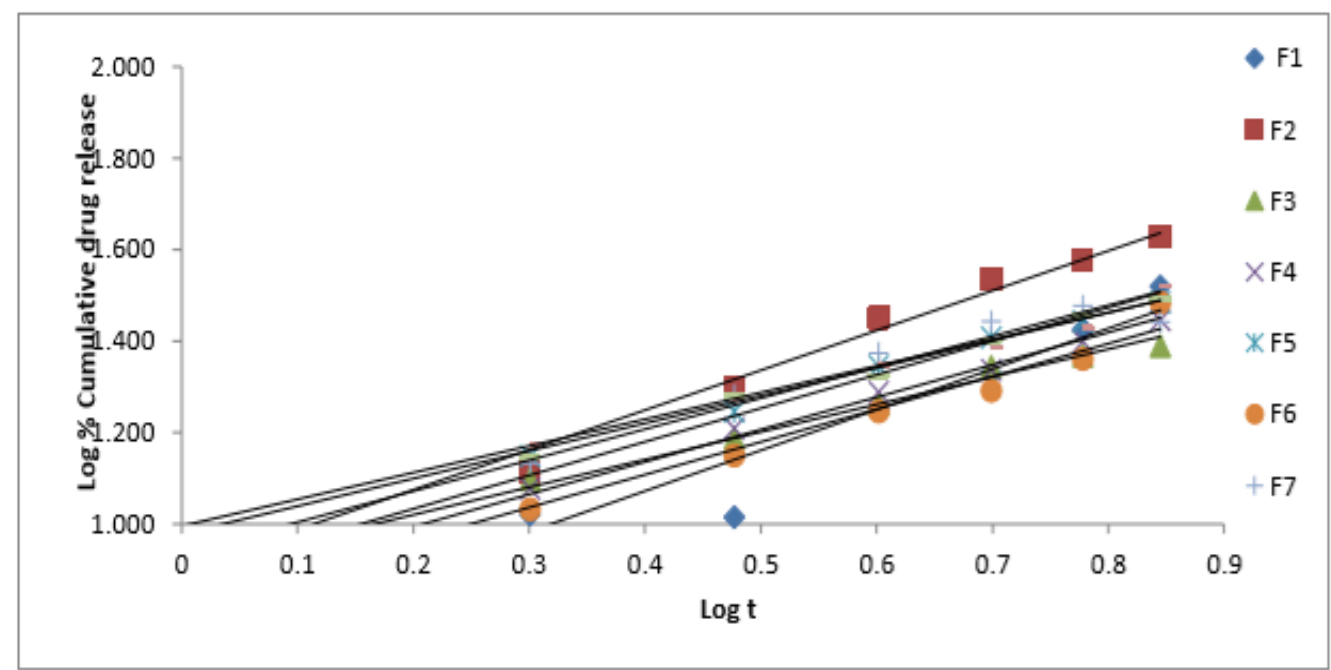

Figure 7(c): plot of $\log \%$ CDR v/s log time (Peppas Model)

\section{Higuchi model}

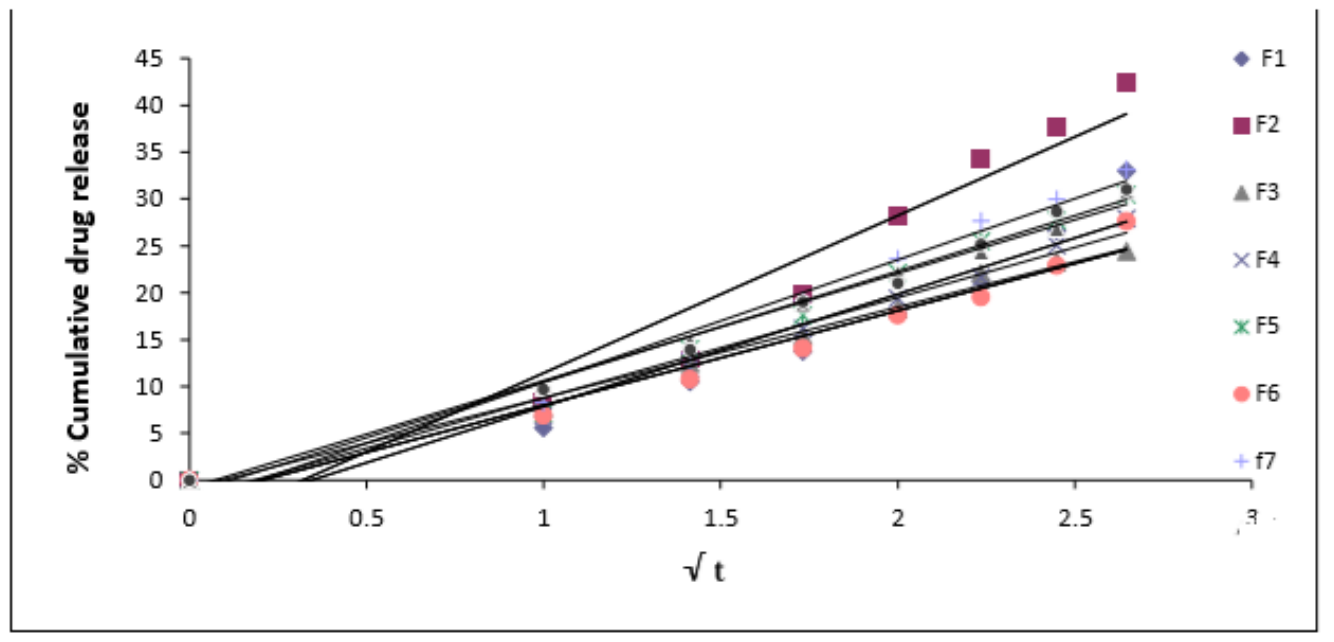

Figure 7 (d): Plot of \% CDR Vs vt (Higuchi model)

In order to study the exact mechanism of drug release from proniosomes loaded telavancin, drug release data were fit into various mathematical models zero order, first order, higuchi models and peppa's and were shown in fig no 7(a), 7(b), 7(c),7(d) and regression co-efficient were depicted in Table No 5. These values were compared with each other for model fitting equation.

Based on the highest regression values ( $r$ ), the best fit model for F1 was zero order, F2 was first order and for F3 to F7 it was Peppa's model. 
All the formulations were then fitted into korsmeyer-peppa's model and $\mathrm{n}$ values are reported in Table 5 For all the formulations, the ' $n$ ' value was in the range of 0.73-1 indicating non fickian diffusion.

\section{Stability studies:}

Stability study of the vesicles is the major determinant for the stability of the formulations. The study was carried for drug entrapment and accelerated condition $\left[30 \pm 2{ }^{\circ} \mathrm{C}\right.$ at $\left.65 \pm 5 \% \mathrm{RH}\right]$ and refrigeration condition $8 \pm 2{ }^{\circ} \mathrm{C}$. The stability data of proniosomes at $8 \pm 2{ }^{\circ} \mathrm{C}$ and $\left[30 \pm 2{ }^{\circ} \mathrm{C}\right.$ at 65 $\pm 5 \% \mathrm{RH}]$ is given in Table 6

According to the data obtained, formulations stored at refrigeration condition showed higher results compared to the formulations which is stored at accelerated condition.

Table 6: Stability data of various proniosomal formulations

\begin{tabular}{|c|c|c|c|c|c|}
\hline \multirow{2}{*}{$\begin{array}{l}\text { Formulation } \\
\text { code }\end{array}$} & \multicolumn{2}{|c|}{ Entrapment Efficiency (\%) } & \multirow{2}{*}{$\begin{array}{l}\text { Formulation } \\
\text { code }\end{array}$} & \multicolumn{2}{|c|}{ Entrapment Efficiency $(\%)$} \\
\hline & $\begin{array}{l}\text { Initial } \\
\left(8 \pm 2{ }^{\circ} \mathrm{C}\right)\end{array}$ & $\begin{array}{l}\text { Initial } \\
\left(30 \pm 2{ }^{\circ} \mathrm{C}\right. \\
\text { at } 65 \pm 5 \% \quad \mathbf{R H})\end{array}$ & & $\begin{array}{l}\text { After } 4 \\
\text { weeks } \\
\left(8 \pm 2{ }^{\circ} \mathrm{C}\right) \\
\end{array}$ & $\begin{array}{l}\text { After } 4 \text { weeks } \\
\left(30 \pm 2{ }^{\circ} \mathrm{C}\right. \\
\text { at } 65 \pm 5 \% \mathrm{RH})\end{array}$ \\
\hline F1 & 55.5 & 45.8 & F1 & 55.1 & 43.6 \\
\hline $\mathrm{F} 2$ & 63.5 & 52.75 & $\mathrm{~F} 2$ & 62.5 & 50.75 \\
\hline F3 & 51.85 & 62.96 & F3 & 50.58 & 60.56 \\
\hline $\mathrm{F} 4$ & 69.68 & 75.56 & F4 & 68.12 & 73.86 \\
\hline F5 & 79.6 & 80.26 & F5 & 77.20 & 79.21 \\
\hline F6 & 93.23 & 90.26 & F6 & 92.36 & 88.23 \\
\hline F7 & 88.69 & 70.25 & F7 & 86.56 & 69.28 \\
\hline
\end{tabular}

\section{CONCLUSION}

In the present study telavancin proniosomal gel was prepared using co-acervation phase separation method and used in the treatment of multidrug resistant gram-positive infections as antimicrobial agent. Formulation F6 selected as the optimized formulation and shows highest drug permeation of $72.01 \%$, it also shows good sustained release properties. The results of the present study indicated that telavancin proniosomal gel containing, Cholesterol, lecithin and Span 60 as surfactant produced prolonged release of drug. The proniosomal gel could be an effective alternative carrier for delivering the drugs through transdermal route.

\section{REFERENCE:}

1. Bharti N, Loona S, Khan MMU. Proniosomes: A Recent advancement in Nanotechnology as a drug carrier. Int J Pharm Sci Rev Res 2012; 12(1):67-75.

2. Peeyush V, Ram A. Non-ionic provesicular drug carrier: An overview. Asian J Pharm Clin Res 2013;6(1):38- 42. 
3. Sundhamani T, Priyadarisini N, Radhakrishnan M. Proniosomes- A promising drug carriers. Int J Pharm Tech Res 2010; 2:1446-54.

4. Giddi HS, Arunagirinathan MA, Bellare JR. Self-assembled surfactant nano-structures important in drug delivery: A review. Indian J Exp Bio 2007; 45:133-59.

5. Pankaj S, Rini T, Dandagi PM. Formulation and evaluation of proniosomes based drug delivery system of the antifungal drug clotrimazole. Int J Pharm Sci Nanotech 2013; 6(1):1945-51

6. Ryan JA, Kerry LL.A novel lipoglycopeptide antimicrobial agent. Ame J Health Sys Pharm 2007;64(22):2335-48.

7. Sharma BS, Bhogale V, Adepu AR, Patil ST, Sangu SK. Proniosomes: A novel provesicular drug delivery system. Int J Pharm Res 2015; 4(1); 105-19.

8. Sambhakara S, Paliwal S, Sharma S, Singh B. Formulation of Risperidone loaded proniosomes for effective transdermal delivery. Bull Fac Pharm Cairo Univ 2017; 55:23947.

9. Pankaj S, Rini T, Dandagi PM. Formulation and evaluation of proniosomes based drug delivery system of the antifungal drug Clotrimazole. Int J Pharm Sci Nanotech 2013; 6(1):1945-51.

10. Shweta V, Sunil KB, Satish S. Formulation and evaluation of proniosomal gel of Diclofenac sodium using $3^{2}$ factorial designs. Int J Bio Pharm 2015; 6(1):48-54.

11. Patil HN, Hardikar SR, Bhosale AV. Formulation, development and evaluation gel of carvediol. Int J Pharm Sci 2012; 4(1):191-94.

12. Thulasi CG, Harini G, Vandana KR, Jayashree V and Prasanna RY. In-vitro dynamics of ibuprofen incorporated proniosomal gel. Int J Pharm Edu and Res; 2013; 47(4); 59-64.

13. Gupta A, Prajapathi SK, Balamurugan M, Bhatia MSD. Design and development of proniosomal transdermal drug delivery system of captopril. Trop J Pharm Res 2011; 6(2): 687-93.

14. Kulkarni GT, Gowthamarajan K, Suresh B. Stability testing of Pharmaceutical Products: An overview. Indian J Pharm Edu 2004; 38(4): 194-202.

\section{AJPHR is}

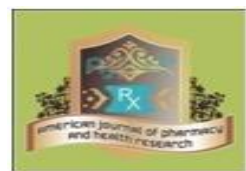

Peer-reviewed monthly

Rapid publication

Submit your next manuscript at editor@ajphr.com / editor.ajphr@gmail.com 